\title{
Oxalate and chloride absorption by the rabbit colon: sensitivity to metabolic and anion transport inhibitors
}

\author{
MARGUERITE HATCH, R W FREEL, A M GOLDNER, AND D L EARNEST \\ From the Departments of Internal Medicine (Gastroenterology) and Physiology, College of Medicine, \\ University of Arizona, Tucson, Arizona, USA
}

SUMmaRY The effects of transport inhibitors on the movements of oxalate and chloride across the isolated short circuited rabbit colon were studied. Net oxalate absorption was shown in this species and was shown to be an energy dependent process as indicated by its sensitivity to 2-4 dinitrophenol (DNP) $10^{-4} \mathrm{M}$. Mucosal addition of 4-acetamido-4-isothiocyano-2,-stilbene-2,2' disulfonic acid (SITS) $10^{-4} \mathrm{M}$ abolished the net flux of both oxalate and chloride. Acetazolamide $(8 \mathrm{mM})$ in bicarbonate free buffer significantly reduced the mucosal to serosal flux of both anions. These results suggest that in rabbit colon, oxalate and chloride share a common transport pathway and implicate the chloride bicarbonate exchange system. This study also confirms that chloride absorption by the short circuited rabbit colon is an electrically silent process and presents evidence that suggests that chloride absorption is mediated by a chloride bicarbonate exchange system located in the apical membrane of absorbing colonic epithelial cells.

The clinical importance of oxalate has been derived from its relative insolubility in urine and consequently its major role in the pathogenesis of renal calculi. A portion of the oxalate excreted in urine comes from oxalate in food which is absorbed into the body across intestinal mucosa. It has now been documented that intestinal oxalate absorption is abnormally increased in patients with a variety of intestinal disorders ${ }^{1-5}$ and in some individuals with oxalate renal stones but with no other apparent underlying disease. ${ }^{6}$ The mechanism postulated to describe intestinal oxalate absorption is passive diffusion. ${ }^{7-10}$ In a previous study, however, we found net transport of oxalate across rat colon. ${ }^{11}$ In this report, we confirm and extend these observations using the isolated rabbit colon. Our results suggest that oxalate movements across this tissue are closely related to chloride transport, and new information is also presented regarding the mechanism of chloride absorption by the isolated rabbit colon.

\section{Methods}

ANIMALS

Non-fasting male New Zealand white rabbits (2-3

Address for correspondence: David L Earnest, MD, Department of Internal Medicine, Section of Gastroenterology, University of Arizona, College of Medicine, Tucson, Arizona, 85724, USA.

Received for publication 3 June 1983 $\mathrm{kg}$ ) were anaesthetised with pentobarbital. The descending colon was excised, rinsed with a buffered saline solution (see below) and partially stripped of its serosal layers as described elsewhere. ${ }^{12}$ Flat sheets of colonic mucosa were mounted in modified Ussing chambers with an exposed tissue area of $1 \cdot 13-3 \cdot 14 \mathrm{~cm}^{2}$, and were bathed on either side by $12-15 \mathrm{ml}$ of buffered solution.

\section{BATHING MEDIA}

The normal bathing medium contained (concentrations in mmol/l): $140 \mathrm{Na}^{+}, 123 \mathrm{Cl}^{-}, 5 \cdot 4 \mathrm{~K}^{+}, 1 \cdot 2$ $\mathrm{Mg}^{2+}, 1 \cdot 2 \mathrm{Ca}^{2+}, 21 \mathrm{HCO}_{3}^{-}, 0 \cdot 6 \mathrm{HPO}_{4}^{-}, 2 \cdot 4 \mathrm{H}_{2} \mathrm{PO}_{4}^{-}$, and 10 glucose. This solution was gassed with $95 \%$ $\mathrm{O}_{2} / 5 \% \mathrm{CO}_{2}$ and maintained at $37^{\circ} \mathrm{C}$. The series of experiments using acetazolamide were performed in bicarbonate free buffer. This solution was gassed with $100 \% \quad \mathrm{O}_{2}$ and $\mathrm{HCO}_{3}^{-}$was replaced by equimolar amounts of $\mathrm{Cl}^{-}$. Both saline solutions had $\mathrm{pH}$ values between 7.3 and 7.5 under experimental conditions.

The following compounds were evaluated with respect to their effects on ion transport: $2-4$ dinitrophenol (DNP) $10^{-4} \mathrm{M}$ (Sigma); 4-acetamido-4' isothiocyano-2,-stilbene-2, $2^{\prime}$-disulfonic acid (SITS) $10^{-4} \mathrm{M}$ (ICN); acetazolamide $8 \mathrm{mM}$ (Sigma).

SHORT CIRCUITING TECHNIQUES

Tissues were short circuited by automatic voltage 
clamping devices (WP Instruments DVC 100) which compensated for the solution resistance between the voltage sensing electrodes and the tissue. Tissue conductance $\left(\mathrm{G}_{\mathrm{T}}, \mathrm{mS} / \mathrm{cm}^{2}\right)$ was calculated from the measured short circuit current (Isc, $\mu \mathrm{A} / \mathrm{cm}^{2}$ ) and the open circuit transmural electrical potential (PD, $\mathrm{mV}$ ) measured immediately after the clamp current was turned off.

\section{ION FLUX MEASUREMENTS}

Transmural fluxes of oxalate $\left({ }^{14} \mathrm{C}\right.$-oxalate, Amersham) and either sodium $\left({ }^{22} \mathrm{Na}\right.$, New England Nuclear) or chloride $\left({ }^{36} \mathrm{Cl}\right.$, New England Nuclear) were measured simultaneously under short circuit conditions. In order to prevent formation of insoluble calcium oxalate, the total concentration of oxalate never exceeded $1.7 \mu \mathrm{M}$. This concentration was low enough to prevent formation of calcium oxalate as calculated from the solubility product for this compound. An equimolar amount of sodium oxalate was added to the unlabelled side of the tissue.

Unidirectional tracer fluxes of oxalate, sodium, and chloride were measured at $\mathbf{3 0}$ minute intervals for a 90 minute control period after an initial 20 minute equilibration period. At 30 minute intervals $0.5 \mathrm{ml}$ samples were removed from the unlabelled side, dissolved in $5 \mathrm{ml}$ Beta Phase (West Chem Products), and analysed in a liquid scintillation spectrometer (Tracor Mark III). This aliquot was replaced by an equal volume of unlabelled buffer solution. After the addition of the appropriate inhibitor to the bathing media, ion fluxes were measured for an additional 90 minute period at 30 minute intervals. Net solute fluxes were calculated from the measured differences in unidirectional fluxes across adjacent pieces of tissue from the same animal and having similar conductances (difference $\leqslant 20 \%$ ).

\section{STATISTICAL TESTS}

Results are presented as the mean value plus or minus one standard error (mean \pm SEM) based upon the number of tissues or tissue pairs studied. Student's $t$ test was used to evaluate the differences between means of paired or unpaired variates. Unless otherwise noted, differences are considered significant if $\mathrm{p}<0.05$

\section{Results}

The unidirectional and calculated net fluxes of oxalate across the rabbit descending colon are presented in Table 1 with the associated electrical characteristics of this tissue. Under short circuit conditions with identical solutions bathing the two
Table 1 Transepithelial oxalate fluxes and electrical characteristics of rabbit descending colon in vitro. Values presented represent the mean \pm 1 SEM for 51 tissues examined throughout the year

\begin{tabular}{llllll}
\hline $\begin{array}{l}J_{s m}^{o x} \\
\left(p m o l / \mathrm{cm}^{2} / \mathrm{hr}\right)\end{array}$ & $\begin{array}{c}J_{\text {net }}^{o x} \\
(\mathrm{xs}\end{array}$ & $\begin{array}{l}P D \\
(\mathrm{mV})\end{array}$ & $\begin{array}{l}I s c \\
\left(\mu \mathrm{A} / \mathrm{cm}^{2}\right)\end{array}$ & $\begin{array}{l}G_{T} \\
\left(\mathrm{mS} / \mathrm{cm}^{2}\right)\end{array}$ \\
\hline $5 \cdot 23$ & 11.56 & $6 \cdot 13$ & 11.9 & 52.4 & 4.20 \\
$\pm 0 \cdot 19$ & \pm 0.59 & \pm 0.45 & \pm 0.7 & \pm 2.6 & $\pm 0 \cdot 19$ \\
\hline
\end{tabular}

sides of the tissue, the $M$ to $S$ flux of oxalate exceeds the $\mathrm{S}$ to $\mathrm{M}$ flux by a factor of two. The calculated net absorptive flux of oxalate is significantly different from zero $(p<0 \cdot 001)$ and the unidirectional fluxes are significantly different from each other $(p<0.001)$. It is important to note, however, that during the time course of these studies we observed variability in the magnitude of the net flux which was primarily due to variation in the $\mathrm{M}$ to $\mathrm{S}$ component (Tables 1-4). In some groups of animals the net flux was not significantly different from zero. The physiological basis for this variability is not clear at the present time.

The energy dependence of net oxalate transport was evaluated by adding $10^{-4} \mathrm{M}$ DNP to the bathing solutions after control fluxes were established. The unidirectional and net fluxes of sodium were measured simultaneously to verify the efficacy of DNP as a metabolic inhibitor. As shown in Table 2, DNP significantly reduced $I_{s c}$ and abolished $J_{\text {net }}^{\mathrm{Na}}$. As net sodium absorption is dependent upon cellular energy, DNP appears to effectively interrupt ATP production in the rabbit colon. Dinitrophenol also abolished net oxalate absorption. Although DNP was effective in reducing net solute transport, prolonged exposure of the tissue to this agent promoted large increases in the passive (S to $M$ ) fluxes of both sodium and oxalate. The $M$ to $S$ flux of oxalate after DNP addition is comprised of two components: active and passive. The decrease in the active component appears to be masked because DNP also effects the passive permability of the tissue. Despite these complications, it is clear that net oxalate absorption is metabolically dependent.

Based upon the fact that oxalate $\left(\mathrm{pKa}_{1}=1 \cdot 23\right.$, $\mathrm{pKa}_{2}=3.83$ ) exists primarily as a divalent anion in the buffers used here, the sensitivity of the oxalate transport system to known inhibitors of anion transport was examined. In order to assess the effectiveness of anion transport inhibition, chloride fluxes were determined simultaneously with those of oxalate in control and experimental conditions.

The effects of mucosal addition of $10^{-4} \mathrm{M}$ SITS were examined with respect to chloride and oxalate movements across the rabbit colon. As shown in 
Table 2 Effects of $10^{-4} \mathrm{M}$ DNP on the transepithelial fluxes of sodium and oxalate and associated electrical changes across the rabbit colon. Results are presented as the mean \pm I SEM

\begin{tabular}{|c|c|c|c|c|c|c|c|c|}
\hline Condition & $J_{s m}^{o x}$ & $\begin{array}{l}J_{m s}^{o x} \\
\left.\mathrm{nol} / \mathrm{cm}^{2} / \mathrm{h}\right)\end{array}$ & $J_{n e t}^{o x}$ & $J_{s m}^{N a}$ & $\begin{array}{l}J_{m s}^{N a} \\
\left.E q / \mathrm{cm}^{2} / h\right)\end{array}$ & $J_{\text {nel }}^{\mathrm{Na}}$ & $\begin{array}{l}\text { Isc } \\
\left(\mu \mathrm{A} / \mathrm{cm}^{2}\right)\end{array}$ & $\begin{array}{l}G_{T} \\
\left(m S / \mathrm{cm}^{2}\right)\end{array}$ \\
\hline Control & $\begin{array}{l}5 \cdot 17 \pm 0 \cdot 52 \\
(13)\end{array}$ & $\begin{array}{l}9 \cdot 39 \pm 0.92 \\
(13)\end{array}$ & $\begin{array}{l}4.43 \pm 0.67 \\
(12)\end{array}$ & $\begin{array}{l}0 \cdot 58 \pm 0 \cdot 06 \\
(13)\end{array}$ & $\begin{array}{l}3 \cdot 35 \pm 0 \cdot 29 \\
(17)\end{array}$ & $\begin{array}{l}2 \cdot 24 \pm 0 \cdot 27 \\
(13)\end{array}$ & $\begin{array}{l}53 \cdot 1 \pm 3 \cdot 6 \\
(30)\end{array}$ & $\begin{array}{l}4 \cdot 45 \pm 0 \cdot 37 \\
(30)\end{array}$ \\
\hline $10^{-4}$ DNP & $\begin{array}{l}8 \cdot 75^{*} \pm 0 \cdot 89 \\
(13)\end{array}$ & $\begin{array}{l}9 \cdot 24 \pm 1 \cdot 35 \\
(9)\end{array}$ & $\begin{array}{l}1.49+ \pm 1.59 \\
\text { (9) }\end{array}$ & $\begin{array}{l}1 \cdot 41^{*} \pm 0.20 \\
(14)\end{array}$ & $\begin{array}{l}1.92^{*} \pm 0.29 \\
(9)\end{array}$ & $\begin{array}{l}0.64^{*} \pm 0.35 \\
(9)\end{array}$ & $\begin{array}{l}6 \cdot 4^{*} \pm 0 \cdot 8 \\
(28)\end{array}$ & $\begin{array}{l}5 \cdot 07 \pm 0.55 \\
(28)\end{array}$ \\
\hline
\end{tabular}

( ) = number of tissues or tissue pairs examined. For net flux, only tissue pairs were used.

* Significantly different from control. + Not significantly different from zero.

Table 3, under control conditions both chloride and oxalate are absorbed. The magnitude of $\mathrm{J}_{\text {net }}^{\text {ox }}$ was similar to that presented earlier (Tables 1 and 2). Addition of $10^{-4} \mathrm{M}$ SITS abolished the net flux of both anions, primarily by reducing the $M$ to $S$ unidirectional fluxes. The abolition of net chloride absorption by mucosal SITS is in accord with its known action on the $\mathrm{Cl}^{-}-\mathrm{HCO}_{3}^{-}$exchange systems ${ }^{1314}$ and the probable existence of such an exchange system in the rabbit colon. ${ }^{15}$ Because SITS treatment had no effect on the measured short circuit current, the $\mathrm{Cl}^{-}-\mathrm{HCO}_{3}^{-}$exchange mechanism must be tightly coupled in the rabbit colon. During sodium chloride absorption, the Isc in rabbit colon has been attributed to net sodium transport only. ${ }^{15}$ Because oxalate transport was abolished without significant change in Isc, it is unlikely that oxalate transport in rabbit colon is directly linked to sodium transport. In contrast, the fact that mucosal SITS produced similar effects on $\mathrm{J}_{\mathrm{ms}}^{\mathrm{ox}}$ and $\mathrm{J}_{\mathrm{ms}}^{\mathrm{Cl}}$ suggests that oxalate and chloride may possibly share a common anion transport pathway. We have carried out preliminary studies to investigate such a relationship.

As chloride absorption in rabbit colon occurs via a chloride bicarbonate exchange system, ${ }^{15}$ alteration in chloride absorption induced by modification of intracellular bicarbonate should be accompanied by similar changes in oxalate absorption if chloride and oxalate absorption proceed by the same or a parallel transport mechanism. In order to test this possibility, the effects of $\mathrm{HCO}_{3}^{-}$free buffers containing acetazolamide, a carbonic anhydrase inhibitor, were examined with respect to oxalate and chloride transport. As shown in Table 4, under control conditions (also performed in $\mathrm{HCO}_{3}^{-}$-free solutions), there is a net chloride flux. This net flux, presumably resulting from intracellular generation of bicarbonate, was significantly less than that occurring in a bicarbonate containing buffer (Table 3). The addition of $8 \mathrm{mM}$ acetazolamide completely abolished this residual chloride absorption without producing major changes in the electrical characteristics of the tissue. Abolition of chloride transport was accompanied by a $50 \%$ reduction in net oxalate absorption. This reduction in net transport of both anions resulted from a decrease in the $\mathrm{M}$ to $\mathrm{S}$ component. The reason that $\mathrm{J}_{\text {net }}^{\text {ox }}$ was not totally abolished is unclear and may reflect presence of other anion transport systems. Under control conditions, however, net oxalate absorption was almost twice that observed in the other experiments.

\section{Discussion}

In a previous study, we observed net absorptive transport of oxalate across the rat colon. ${ }^{11}$ As this net absorptive flux of oxalate was across short circuited sheets of tissue bathed on both sides by identical solutions, we suggested that a component

Table 3 Effects of $10^{-4} \mathrm{M}$ SITS (mucosal addition) on the transepithelial fluxes of chloride and oxalate and on associate electrical changes across the rabbit colon. Results are presented as the mean $\pm 1 S E M$

\begin{tabular}{|c|c|c|c|c|c|c|c|c|}
\hline Condition & $J_{s m}^{o x}$ & $\begin{array}{c}J_{m s}^{o x} \\
\left.\mathrm{nol} / \mathrm{cm}^{2} / \mathrm{h}\right)\end{array}$ & $J_{\text {net }}^{o x}$ & $J_{s m}^{C l}$ & $\begin{array}{c}J_{m s}^{C l} \\
\left.E q / c m^{2} / h\right)\end{array}$ & $J_{n e t}^{C l}$ & $\begin{array}{l}\text { Isc } \\
\left(\mu \mathrm{A} / \mathrm{cm}^{2}\right)\end{array}$ & $\begin{array}{l}G_{T} \\
\left(m S / \mathrm{cm}^{2}\right)\end{array}$ \\
\hline Control & $\begin{array}{l}5 \cdot 56 \pm 0.45 \\
(11)\end{array}$ & $\begin{array}{l}9 \cdot 72 \pm 1 \cdot 17 \\
(10)\end{array}$ & $\begin{array}{l}4 \cdot 17 \pm 1 \cdot 14 \\
(10)\end{array}$ & $\begin{array}{l}3 \cdot 77 \pm 0 \cdot 22 \\
(12)\end{array}$ & $\begin{array}{l}5 \cdot 03 \pm 0 \cdot 31 \\
(12)\end{array}$ & $\begin{array}{l}1 \cdot 09 \pm 0 \cdot 28 \\
(12)\end{array}$ & $\begin{array}{l}40 \cdot 5 \pm 2 \cdot 5 \\
(45)\end{array}$ & $\begin{array}{l}3 \cdot 80 \pm 0 \cdot 22 \\
(45)\end{array}$ \\
\hline $10^{-4}$ SITS & $\begin{array}{l}6 \cdot 23 \pm 0 \cdot 82 \\
(9)\end{array}$ & $\begin{array}{l}6 \cdot 62 \pm 0.59 \\
(9)\end{array}$ & $\begin{array}{l}0 \cdot 46+ \pm 1 \cdot 18 \\
\text { (9) }\end{array}$ & $\begin{array}{l}3.92 \pm 0.32 \\
(10)\end{array}$ & $\begin{array}{l}4.41^{*} \pm 0 \cdot 32 \\
(10)\end{array}$ & $\begin{array}{l}0.27+ \pm 0.32 \\
(10)\end{array}$ & $\begin{array}{l}35 \cdot 9 \pm 2 \cdot 4 \\
(42)\end{array}$ & $\begin{array}{l}4 \cdot 38 \pm 0 \cdot 27 \\
(42)\end{array}$ \\
\hline
\end{tabular}

( ) = number of tissues or tissue pairs examined. For net flux, only tissue pairs were used.

* Significantly different from control. † Not significantly different from zero. 
Table 4 Effects of $8 \mathrm{mM}$ acetazolamide (mucosal and serosal addition) in a $\mathrm{HCO}_{3}^{-}$-free solution on the transepithelial fluxes of chloride and oxalate and associated electrical changes across the rabbit colon. Results are expressed as the mean $\pm 1 S E M$

\begin{tabular}{|c|c|c|c|c|c|c|c|c|}
\hline Condition & $J_{s m}^{o x}$ & $\begin{array}{l}J_{m s}^{o x} \\
\left.\mathrm{nol} / \mathrm{cm}^{2} / \mathrm{h}\right)\end{array}$ & $J_{\text {net }}^{o x}$ & $(\mu$ & $\begin{array}{l}J_{m s}^{C l} \\
\left.E q / c m^{2} / h\right)\end{array}$ & $J_{\text {net }}^{C l}$ & $\begin{array}{l}\text { Isc } \\
\left(\mu A / \mathrm{cm}^{2}\right)\end{array}$ & $\begin{array}{l}G_{T} \\
\left(m S / \mathrm{cm}^{2}\right)\end{array}$ \\
\hline Control & $\begin{array}{l}6 \cdot 73 \pm 0 \cdot 67 \\
(14)\end{array}$ & $\begin{array}{l}17 \cdot 28 \pm 2 \cdot 05 \\
(13)\end{array}$ & $\begin{array}{l}10 \cdot 67 \pm 1 \cdot 59 \\
(11)\end{array}$ & $\begin{array}{l}3 \cdot 86 \pm 0 \cdot 25 \\
(15)\end{array}$ & $\begin{array}{l}4 \cdot 54 \pm 0 \cdot 20 \\
(13)\end{array}$ & $\begin{array}{l}0 \cdot 68 \pm 0 \cdot 26 \\
(13)\end{array}$ & $\begin{array}{l}20 \cdot 9 \pm 2 \cdot 6 \\
(27)\end{array}$ & $\begin{array}{l}3 \cdot 66 \pm 0 \cdot 16 \\
(27)\end{array}$ \\
\hline Acetazolamide & $\begin{array}{l}5 \cdot 06 \pm 0.60 \\
(13)\end{array}$ & $\begin{array}{l}10 \cdot 36^{*} \pm 1 \cdot 41 \\
(12)\end{array}$ & $\begin{array}{l}5 \cdot 54^{*} \pm 1 \cdot 17 \\
(9)\end{array}$ & $\begin{array}{l}2 \cdot 95^{*} \pm 0 \cdot 20 \\
(13)\end{array}$ & $\begin{array}{l}3 \cdot 13^{*} \pm 0 \cdot 32 \\
(12)\end{array}$ & $\begin{array}{l}0 \cdot 27 \dagger \pm 0.37 \\
(12)\end{array}$ & $\begin{array}{l}33 \cdot 5^{*} \pm 3 \cdot 1 \\
(27)\end{array}$ & $\begin{array}{l}3 \cdot 69 \pm 0 \cdot 27 \\
(27)\end{array}$ \\
\hline
\end{tabular}

( ) = number of tissues or tissue pairs examined. For net flux, only tissue pairs were used.

${ }^{*}$ Significantly different from control. + Not significantly different from zero.

of colonic oxalate absorption was an active, metabolically dependent process. In the present study, rabbit colonic mucosa was chosen to further evaluate the mechanism of oxalate transport because the isolated rabbit colon is viable for longer periods of time than isolated rat mucosa and the transport properties of rabbit tissue are relatively simple. ${ }^{15}$

The present results verify that isolated rabbit colon, like rat colon, is capable of net absorption of oxalate under short circuit conditions. In addition, the implication that net oxalate transport is dependent upon the availability of metabolic energy has been confirmed in the present study by using DNP. Although the data are not presented, in preliminary experiments, we also observed abolition of net transport of oxalate when tissues were continuously gassed with $100 \%$ nitrogen.

The calculated permeability coefficient of oxalate for rabbit colon (based upon an average $\mathrm{J}_{\mathrm{sm}}^{\mathrm{ox}}=5 \cdot 8$ $\mathrm{pmol} / \mathrm{cm}^{2} / \mathrm{h}$ ) is $1.0 \times 10^{-6} \mathrm{~cm} / \mathrm{sec}$, or about six times smaller than that observed in the rat colon under identical conditions. These differences most simply reflect the fact that rabbit epithelium has a much lower transepithelial conductance $\left(\mathrm{G}_{\mathrm{T}}=4.0 \mathrm{mS} / \mathrm{cm}^{2}\right)$ than does rat colon $\left(\mathrm{G}_{\mathrm{T}}=12 \cdot 0 \mathrm{mS} / \mathrm{cm}^{2}\right)$.

The magnitude of the absorptive flux of oxalate across the rabbit colon was variable and generally only $25-50 \%$ of that observed in the rat preparation. In addition, the chloride absorptive capacity of the rabbit colon, which is dependent upon the integrity of the $\mathrm{Cl}-\mathrm{HCO}_{3}^{-}$exchange system, was only $30 \%$ of that observed in the rat colon where a $\mathrm{Na}^{+}$coupled $\mathrm{Cl}^{-}$influx system is also present.

Frizzel et $a l^{15}$ previously established that chloride absorption by the rabbit colon is an electrically neutral, sodium independent process. To explain their observations they suggested that a tightly coupled $\mathrm{Cl}^{-} \mathrm{HCO}_{3}^{-}$exchange process mediates net chloride absorption in this tissue. ${ }^{15}$ Two aspects of the results of our study give convincing support for this concept. First, there was significant reduction of both $\mathrm{J}_{\mathrm{ms}}^{\mathrm{Cl}}$ and $\mathrm{J}_{\text {net }}^{\mathrm{Cl}}$ in bicarbonate free solutions containing a potent carbonic anhydrase inhibitor (acetazolamide) without altering $\mathrm{I}_{\text {sc. }}$. This clearly indicates that chloride absorption is both electrically silent and bicarbonate dependent. Our data also confirm that $\mathrm{HCO}_{3}^{-}$-free solutions alone are ineffective in abolishing $\mathrm{J}_{\text {net }}{ }^{\mathrm{Cl}}{ }^{15}$ Thus, the process of chloride absorption by rabbit colon is ultimately dependent upon endogenous $\mathrm{HCO}_{3}^{-}$production. Secondly, application of the disulfonic stilbene SITS, to the mucosal side of the rabbit colon abolished $\mathrm{J}_{\text {net }}^{\mathrm{Cl}}$ principally by reducing the $\mathrm{M}$ to $\mathrm{S}$ component. This effect occurs without substantial alteration in the sodium generated short circuit current. Specific inhibition of $\mathrm{Cl}^{-}-\mathrm{HCO}_{3}^{-}$exchange systems by SITS has previously been observed in a variety of symmetrical cells ${ }^{13}$ and epithelial tissues. $^{14} 16$ Thus, it may be reasonably concluded that the first step of active chloride absorption by the rabbit colon is mediated by a $\mathrm{Cl}^{-}-\mathrm{HCO}_{3}^{-}$exchange mechanism located in the apical membrane of the absorptive cell.

In view of the fact that an anion stimulated ATPase has not been identified in colonic epithelia ${ }^{17}$ and given the requirement for endogenous $\mathrm{HCO}_{3}^{-}$ production for net chloride absorption observed here, it would appear that the $\mathrm{Cl}^{-}-\mathrm{HCO}_{3}^{-}$exchange system represents the 'active' step in transepithelial chloride absorption. (More appropriately, the $\mathrm{Cl}^{-}$$\mathrm{HCO}_{3}^{-}$exchange process is secondarily active, to acknowledge the indirect dependence on energy availability.) In such a scheme, chloride is accumulated intracellularly, above its electrochemical gradient, ${ }^{18}$ by virtue of the coupled counterflow of $\mathrm{HCO}_{3}^{-}$moving down its electrochemical gradient into the mucosal solution. Simple chloride diffusion across the basolateral membrane would then provide for the vectorial transport of chloride across this tissue. Schultz ${ }^{17}$ has estimated that if intracellular $\mathrm{pH}$ is about $7 \cdot 0$, then the calculated $\mathrm{HCO}_{3}^{-}$activity gradient would be sufficient to drive the uphill accumulation of 
chloride across the apical border of the rabbit colon in vitro. Although the acetazolamide and SITS sensitivity of $\mathrm{Cl}^{-}$absorption reported herein strongly supports this model for $\mathrm{Cl}^{-}-\mathrm{HCO}_{3}^{-}$ exchange, ultimate verification will depend upon measurement of intracellular chloride activity and/ or intracellular $\mathrm{pH}$ in the absorptive cells of the colon.

We consider it unlikely that net oxalate transport by rabbit colonic mucosa is sodium linked since wide changes in oxalate transport were observed without alteration in short circuit current. In rabbit colon, the Isc is known to result solely from active sodium transport. ${ }^{15}$

It is also unlikely that rabbit colonic epithelium possesses a transport mechanism which is specific for only oxalate. More probably the oxalate anion competes with the dominant anions of the system for their respective transport mechanisms. In the system used in these experiments, the anions were chloride, phosphate, and bicarbonate with chloride being predominant. The observed effects of SITS and acetazolamide on oxalate and chloride transport are highly suggestive that at least in rabbit colon, oxalate and chloride share a related transport pathway.

The notion that oxalate is actively transported across membranes and that it can share a common transport pathway with other anions is not new. For example, Cousin and Motais presented evidence that chloride and oxalate share a common transport pathway (the $\mathrm{Cl}^{-}-\mathrm{HCO}_{3}^{-}$exchange system) across the ox erythrocyte membrane. ${ }^{19}$ Knight et al more recently reported that oxalate transport across the proximal tubule of rat kidney is a carrier mediated process. ${ }^{20}$ They suggested that more than one transport system for oxalate is present. These observations, together with the present results of our study, make it likely that an active transport mechanism for oxalate exists in a variety of epithelial membranes. Moreover, the mechanism appears to be an anion transport process. Our data strongly suggest that in rabbit colon a component of oxalate transport is closely associated with net chloride transport. Additional studies will be required to conclusively establish the extent and dependence of this association.

In summary, we have confirmed that chloride absorption by the short circuited rabbit colon is an electrically silent process. We have also presented evidence which indicates that chloride absorption is mediated by a $\mathrm{Cl}^{-}-\mathrm{HCO}_{3}^{-}$exchange system located in the apical membrane of absorbing mucosal cells. We suggest that this exchange process represents the active step in chloride absorption; that is, chloride is accumulated intracellularly at the expense of an outwardly directed bicarbonate ion gradient.

This study also shows net absorption of oxalate in the isolated rabbit colon. The magnitude of net oxalate absorption was less than that previously observed in rat colon. The mechanism for net oxalate absorption in rabbit colon is an energy dependent process which has a sensitivity to anion transport inhibitors which parallels that for chloride.

This work was supported in part by NIH Grants HL 07249 and RR-05675-13.

\section{References}

1 Chadwick VS, Modha K, Dowling RH. Mechnism of hyperoxaluria in patients with ileal dysfunction. $N$ Engl J Med 1973; 289: 172-6.

2 Stauffer JQ, Humphrey MH, Weir GJ. Acquired hyperoxaluria with regional enteritis after ileal resection: role of dietary oxalate. Ann Intern Med 1979; 79: 383-91.

3 Stauffer JQ. Hyperoxaluria and calcium oxalate nephrolithiasis after jejunoileal bypass. Am J Clin Nutr 1977; 30: 64-71.

4 McDonald GB, Earnest DL, Admirand WH. Hyperoxaluria correlates with fat malabsorption in patients with sprue. Gut 1971; 18: 561-6.

5 Earnest DL, Johnson G, Williams HE, Admirand WH. Hyperoxaluria in patients with ileal resection: an abnormality in dietary oxalate absorption. Gastroenterology 1974; 66: 1114-22.

6 Hodgkinson A. Evidence of increased oxalate absorption in patients with calcium containing renal stones. Clin Sci Mol Med 1978; 54: 291-4.

7 Binder HJ. Intestinal oxalate absorption. Gastroenterology 1974; 67: 441-6.

8 Saunders DR, Sillery J, McDonald GB. Regional differences in oxalate absorption by rat intestine: evidence for excessive absorption by the colon in steatorrhea. Gut 1975; 16: 543-8.

9 Caspary WF. Intestinal oxalate absorption: absorption in vitro. Res Exp Med 1977; 171: 13-24.

10 Schwartz SE, Stauffer JQ, Burgess LW, Cheney M. Oxalate uptake by everted sacs of rat colon. Biochim Biophys Acta 1980; 596: 404-13.

11 Freel RW, Hatch M, Earnest DL, Goldner AM. Oxalate transport across the isolated rat colon: a re-examination. Biochim Biophys Acta 1980; 600: 838-43.

12 Binder HJ, Rawlins CL. Electrolyte transport across isolated large intestinal mucosa. Am J Physiol 1973; 225: 1232-9.

13 Cabantchik ZI, Knaug PA, Rothstein A. The anion transport system of the red blood cell. The role of membrane protein evaluated by the use of 'probes'. Biochim Biophys Acta 1978; 515: 239-302. 
14 Brodsky WA, Durham J, Ehrenspeck G. The effects of a disulphonic stilbene on chloride and bicarbonate transport in the turtle bladder. J Physiol 1979; 287: 559-73.

15 Frizzell RA, Koch MJ, Schultz SG. Ion transport by the rabbit colon. I. Active and passive components. $J$ Membr Biol 1976; 27: 297-316.

16 White JF. Bicarbonate-dependent chloride absorption in small intestine: 1980. Ion fluxes and intracellular chloride activities. J Membr Biol 1980; 53: 95-107.

17 Schultz SG. Cellular models of sodium and chloride absorption by mammalian small and large intestine. In:
Field M, Fordtran JS, Schultz SG, eds. Secretory diarrhoea. Bethesda, Maryland: Clinical Physiology Series American Physiology Society, 1980: 1-9.

18 Frizzell RA, Duffey MR. Chloride activities epithelia. Fed Proc 1980; 39: 2860-4.

19 Cousin JL, Motais R. The role of carbonic anhydrase inhibitors on anion permeability into ox red blood cells. J Physiol 1976; 256: 61-80.

20 Knight TF, Senekjian HO, Taylor K, Steplock DA, Weinman EJ. Renal transport of oxalate: effects of diuretics, uric acid and calcium. Kidney Int 1979; 16: $572-6$. 